\title{
First investigation of Staphylococcus argenteus in a Brazilian collections of S. aureus isolated from bovine mastitis
}

\author{
Bruna F. Rossi', Érika C. R. Bonsaglia ${ }^{1 *}$ D, Ivana G. Castilho ${ }^{1}$, Stéfani T. A. Dantas ${ }^{1}$, Hélio Langoni ${ }^{2}$, José C. F. Pantoja ${ }^{2}$,
} Ary Fernandes Júnior ${ }^{1}$, Juliano L. Gonçalves ${ }^{3}$, Marcos V. Santos ${ }^{3}$, Rinaldo A. Mota ${ }^{4}$ and Vera L. M. Rall ${ }^{1}$

\begin{abstract}
Background: Staphylococcus argenteus is a new specie positive coagulase staphylococci. We investigate the presence of $S$. argenteus in isolates previously classified as $S$. aureus, obtained from the milk of cows with mastitis in Brazil.

Results: Among $856 \mathrm{~S}$. aureus tested in chocolate agar, tryptone soya agar and salt egg yolk agar, white or colorless colonies were observed in 185 (21.6\%) isolates. Regarding the ctrOPQMN operon, 111 (60\%) presented the complete cluster. Despite some missing genes in this cluster, the remaining strains (74) were confirmed as $S$. aureus using the nrps gene.

Conclusions: As far as we know, this is the first review of S. aureus collection in Brazil and S. argenteus does not appear to be a significant problem in Brazilian herds.
\end{abstract}

Keywords: S. aureus complex, Staphyloxanthin, nrps gene, Salt egg yolk agar

\section{Background}

Mastitis is a common disease in dairy herds, causing large declines in profitability and harmful effects on animal welfare [1]. It can be caused by a variety of microorganisms and Staphylococcus aureus is one of the most important pathogens isolated from the milk of cows with subclinical mastitis [2].

In 2015 whole genome sequencing (WGS) confirmed that isolates from several clonal S. aureus lineages were sufficiently divergent to be designated as separate coagulase-positive species, included in $S$. aureus complex (SAC). While S. schweitzeri appears to be predominantly associated with wildlife, being restricted to Sub-Saharan Africa [3], S. argenteus has been reported worldwide [4-

\footnotetext{
* Correspondence: erikabonsaglia@gmail.com

${ }^{1}$ Department of Chemical and Biological Sciences, Institute of Biosciences,

Sao Paulo State University - UNESP, Post Office Box 510, Botucatu, Sao Paulo 18618-970, Brazil

Full list of author information is available at the end of the article
}

10] and is predominantly human-associated, although their recovery from several animals already occurred [3]. This new species had already been described before $S$. aureus like CC75/ST 75 [11], with an evolutionary sequence very distant from other S. aureus strains. Nonetheless, S. argenteus presents more than $60 \mathrm{CC}$, such as CC2196 (35 STs), followed by CC1594 (12 STs), CC2198 (7 STs), CC75 (5 STs), and CC2793 (2 STs) [6, 12, 13].

S. argenteus has an average nucleotide identity of 87.4\%, corresponding to a DNA-DNA hybridization value of $33.5 \%$ compared to $S$. aureus $[12,14]$. S. argenteus shares most of the major virulence factors of $S$. aureus, such as staphylococcal enterotoxins (SEs) [15] Antimicrobial resistance genes such as mecA have also been found in $S$. argenteus [16, 17] indicating the presence of mobile genetic islands and horizontal gene transition.

C C The Author(s). 2020 Open Access This article is licensed under a Creative Commons Attribution 4.0 International License, which permits use, sharing, adaptation, distribution and reproduction in any medium or format, as long as you give appropriate credit to the original author(s) and the source, provide a link to the Creative Commons licence, and indicate if changes were made. The images or other third party material in this article are included in the article's Creative Commons licence, unless indicated otherwise in a credit line to the material. If material is not included in the article's Creative Commons licence and your intended use is not permitted by statutory regulation or exceeds the permitted use, you will need to obtain permission directly from the copyright holder. To view a copy of this licence, visit http://creativecommons.org/licenses/by/4.0/ The Creative Commons Public Domain Dedication waiver (http://creativecommons.org/publicdomain/zero/1.0/) applies to the data made available in this article, unless otherwise stated in a credit line to the data. 
Phenotypic differences could be observed after growth in chocolate agar, tryptone soya agar (TSA) and salt egg yolk agar (SEY), as only $S$. aureus has a carotenoid pigment named staphyloxanthin [7, 12, 18] The operon crtOPQMN is responsible for coding the enzymes CrtO, CrtP, CrtQ, CrtM and CrtN, which are essential for staphyloxanthin synthesis [19] and the failure of any of these enzymes leads to the production of white colonies by $S$. argenteus in most agar media [9].

Genotypically, both the specific thermonuclease gene, $n u c$ and 16S rRNA genes, which are used for confirmation of the $S$. aureus species, have identical sequences compared to S. argenteus [6]. But there is a genetic difference that can be used as a discriminative method based on deletion of 60 amino acids in the sequence of $S$. aureus nonribosomal peptide synthetase (NRPS), which does not occur in S. argenteus. Zhang et al. [9] discovered this deletion by comparing open-reading frames of $S$. aureus NCTC 8325 (GenBank no. NC 007795) and S. argenteus MSHR $1132 \mathrm{~T}$ (GenBank no. NC_016941) genomes, using BLAST algorithm. These genomic comparisons confirmed the presence of the intact NRPS gene in S. argenteus. Otherwise, more elaborate techniques are needed to discriminate $S$. argenteus from $S$. aureus, such as multilocus sequence typing (MLST) $[9,20]$.

Reports of this new species and improvements in identification techniques are still recent and therefore strains previously classified as $S$. aureus may be reclassified as $S$. argenteus according to the new characteristics.

Thus, the objective of the study was to investigate the presence of $S$. argenteus in isolates previously classified as $S$. aureus, obtained from the milk of cows with clinical or subclinical mastitis in different regions of Brazil.

\section{Results}

Among the 856 strains (S1 Table) that were seeded onto the different agars, $185(21.6 \%)$ had colonies that were white or colorless, but definitely not yellow. Interestingly, none of the 10 isolates from the state of Rio de Janeiro presented pigmentation, as indicated in Table 1 .
Among 185 non-pigmented strains, $60 \%$ of isolates $(N=$ $111 / 185$ ) presented the complete operon (Table 1). The crtQ gene was the most frequent, present in 157 out of 185 isolates (84.9\%) (S2 Table).

Considering all genes that make up the staphyloxanthin operon $(\operatorname{crt} O, \operatorname{crtP}, \operatorname{crtQ}, \operatorname{crt} M, \operatorname{crt} N), 74$ out of 185 (40\%) non-pigmented isolates did not present at least one of them, and $\operatorname{crt} O$ was the least frequent, according to Table 2 .

The nrps gene was searched only in strains lacking at least one of the staphyloxanthin operon genes. All 74 strains presented amplicons of approximately $160 \mathrm{bp}$, considered to be $S$. aureus according to Zhang et al. [9] as $S$. aureus has a deletion in this gene while $S$. argenteus has a product of approximately $340 \mathrm{bp}$. As all strains were confirmed to be $S$. aureus, no MLST was required.

\section{Discussion}

S. argenteus has been found in other regions of the world in human and animal isolates [3, 9, 21]. However, to date, this microorganism has not been reported in Brazil. According to Moradigaravand et al. [22], S. argenteus presents genes associated with plasmids and other mobile genetic elements previously observed with livestock-associated $S$. aureus, suggesting the need for further research into the presence of $S$. argenteus in dairy herds.

Among the $856 \mathrm{~S}$. aureus this study, none were reclassified as $S$. argenteus, indicating the absence or low incidence of this new species in Brazilian herds. The Amazon is considered one of three main hot spots in the world, along with Australia and Southeast Asia [3] so it is important to research this new species in Brazil since the presence of a hot spot facilitates the spread of this bacteria.

Until now, few collections of $S$. aureus strains were retrospectively analyzed for the study of $S$. argenteus using culture media such as TSA [9] or chocolate agar [7]. SEY agar had been used only in isolation procedures for visualization of white colonies [18]. As a screening method, this phenotypic test, does not seem to be

Table 1 Presence of the operon crtOPQMN genes among non-pigmented S. aureus strains isolated from the milk of cows with clinical and subclinical mastitis, in different states in Brazil

\begin{tabular}{|c|c|c|c|c|c|c|c|}
\hline $\begin{array}{l}\text { States } \\
(\mathrm{N})\end{array}$ & $\begin{array}{l}\text { Non pigmented isolates } \\
\mathrm{N}(\%)\end{array}$ & $\begin{array}{l}\text { crtO } \\
\mathrm{N}(\%)\end{array}$ & $\begin{array}{l}\text { crtP } \\
N(\%)\end{array}$ & $\begin{array}{l}\text { crtQ } \\
\mathrm{N}(\%)\end{array}$ & $\begin{array}{l}\text { crtM } \\
\mathrm{N}(\%)\end{array}$ & $\begin{array}{l}\text { Crt } N \\
\mathrm{~N}(\%)\end{array}$ & $\begin{array}{l}\text { Complete Operon } \\
\text { N (\%) }\end{array}$ \\
\hline SP (615) & $68(11.1)$ & $62(91.2)$ & $56(82.4)$ & $60(88.2)$ & $60(88.2)$ & $66(97.1)$ & $53(77.9)$ \\
\hline MG (130) & $82(63.1)$ & 39 (47.6) & $61(74.4)$ & 63 (76.8) & 48 (58.6) & $56(68.3)$ & $33(40.2)$ \\
\hline PE (57) & $24(42.1)$ & $23(95.8)$ & 24 (100) & $23(95.8)$ & $24(100)$ & $24(100)$ & $23(95.8)$ \\
\hline PR (44) & $1(2.3)$ & $1(100)$ & $1(100)$ & $1(100)$ & $1(100)$ & $1(100)$ & $1(100)$ \\
\hline RJ (10) & $10(100)$ & $1(10)$ & $10(100)$ & $10(100)$ & $6(60)$ & $9(90)$ & $1(10)$ \\
\hline Total (856) & 185 (21.6) & $126(68.1)$ & $152(82.2)$ & 157 (84.9) & $139(75.1)$ & $156(84.3)$ & $111(60)$ \\
\hline
\end{tabular}

SP São Paulo, MG Minas Gerais, PE Pernambuco, PR Paraná, RJ Rio de Janeiro 
Table 2 Genotypic profiles of operon crtOPQMN among nonpigmented $S$. aureus strains isolated from milk of cows with clinical or subclinical mastitis

\begin{tabular}{|c|c|c|c|c|c|}
\hline \multirow[t]{2}{*}{ N (\%) } & \multicolumn{5}{|c|}{ Operon crtOPQMN } \\
\hline & $\mathrm{crtO}$ & crtP & crtQ & crtM & $c r t N$ \\
\hline $111(60)$ & + & + & + & + & + \\
\hline $18(9.7)$ & - & + & + & + & + \\
\hline $13(7.0)$ & - & - & - & - & - \\
\hline $7(3.8)$ & + & - & - & - & + \\
\hline $7(3.8)$ & - & + & + & - & - \\
\hline $6(3.2)$ & - & + & + & - & + \\
\hline $4(2.2)$ & - & - & + & + & + \\
\hline $3(1.6)$ & - & - & - & - & + \\
\hline $2(1.1)$ & + & + & - & + & + \\
\hline $2(1.1)$ & - & - & + & - & - \\
\hline $2(1.1)$ & - & + & + & + & - \\
\hline $1(0.5)$ & + & + & + & - & - \\
\hline $1(0.5)$ & + & + & + & - & + \\
\hline $1(0.5)$ & + & + & + & + & - \\
\hline $1(0.5)$ & + & - & - & - & - \\
\hline $1(0.5)$ & + & - & + & - & + \\
\hline $1(0.5)$ & + & - & + & - & - \\
\hline $1(0.5)$ & - & - & + & - & + \\
\hline $1(0.5)$ & - & + & + & - & + \\
\hline $1(0.5)$ & - & + & - & + & + \\
\hline $1(0.5)$ & - & + & - & - & - \\
\hline $185(100)$ & $126(68.1)$ & $152(82.2)$ & $157(84.9)$ & $139(75.1)$ & 156 (84.3) \\
\hline
\end{tabular}

appropriate as we tested 856 isolates of bovine mastitis milk, with 185 (21.6\%) non-pigmented and none of them were $S$. argenteus. Zhang et al. [9] tested 839 S. aureus isolated from food products, healthy humans and hospital infections in TSA, and 89 (10.6\%) had white colonies, but only six of them (6.7\%) were confirmed to be S. argenteus. Arguidin et al. [7] tested 1903 strains of $S$. aureus isolated from human infections in chocolate agar and found $73(3.8 \%)$ non-pigmented isolates, but only three (4\%) were $S$. argenteus.

Most (60\%) of the non-pigmented S. aureus isolates from this study presented all operon crtOPQMN genes as did those in Zhang et al. [9] who detected the complete crtOPQMN operon in all their non-pigmented S. aureus. In those cases, the lack of pigmentation did not occur due to the absence of one of the genes so other factors must be involved in its expression or regulation.

Kitagawa et al. [23] investigated the absence of the crtM gene to confirm $S$. argenteus species but, as observed in this study, 46 strains confirmed as $S$. aureus also did not present the crtM gene, indicating that its absence is not an exclusive feature of $S$. argenteus.
Using the nrps gene [9], all non-pigmented isolates were confirmed as $S$. aureus, despite the absence of at least one gene in the staphyloxanthin operon. In this technique, the nrps gene product for S. argenteus has a molecular weight of approximately $340 \mathrm{bp}$ while for $S$. aureus the molecular weight is reduced to approximately $160 \mathrm{bp}$. With this, the initial separation between the two species become quick and effective.

The results showed that screening tests using the lack of pigmentation in different culture media and the absence of the $c r t M$ gene did not show high discriminatory power in the differentiation between $S$. aureus and $S$. argenteus. On the other hand, screening using the nrps gene was efficient. MLST is considered the most reliable technique for confirming $S$. argenteus [9]. However, as it is a laborious technique, it needs more effective screening.

\section{Conclusions}

As far as we know, this is the first review of an $S$. aureus collection isolated from clinical and subclinical mastitis in Brazil, and S. argenteus is not yet a significant problem to be considered in cases of mastitis. Besides, the development of a better phenotypic screening test is needed before conducting molecular confirmation, which is more laborious and expensive.

\section{Methods}

\section{Bacterial samples}

A total of 856 strains previously identified as S. aureus were reevaluated. All strains were isolated from the milk of cows with clinical or subclinical mastitis, from 2010 to 2019, from five Brazilian states: São Paulo $(n=615)$, Minas Gerais $(n=130)$, Pernambuco $(n=57)$, Paraná $(n=44)$ and Rio de Janeiro $(n=10)$. The strains are part of the bacterial collection found in the Food Microbiology Laboratory of the Department of Microbiology and Immunology at the Institute of Biosciences of Paulista State University in Botucatu, São Paulo (Brazil). Previously, screening tests for $S$. aureus identification were gram stain, catalase and coagulase tests, and tests for clumping factor. Confirmation through molecular typing was performed by polymerase chain reaction (PCR) using the specific nuclease (nuc) gene [24]. This study was approved by the Committee on Ethics in Animal Use of UNESP $(0136 / 2017)$.

\section{Phenotypic and genotypic identification of S. argenteus}

The initial screening was performed using SEY agar [18], chocolate agar (Oxoid, Basingstoke, UK) [7] and TSA agar (Oxoid, Basingstoke, UK) [9]. All isolates were incubated in Brain and Heart Infusion Broth (Oxoid, Basingstoke, UK) at $37^{\circ} \mathrm{C} / 24 \mathrm{~h}$. After this period, an aliquot of each strain was seeded onto the different agars and 
incubated for $48 \mathrm{~h}$ at $37^{\circ} \mathrm{C}$. After this period, strains showing white colonies or without pigmentation (gray) were suspected of $S$. argenteus and selected for molecular analysis. The operon $\operatorname{crtOPQMN}$ genes (crtO, crtP, $\operatorname{crt} \mathrm{Q}, \operatorname{crt} M$ and $\operatorname{crt} N$ ) were screened by PCR, according to Zhang et al. [9] in all nonpigmented isolates. The nrps gene [9] was tested only in isolates that did not have at least one of the crtOPQMN operon genes. S. aureus MW2, S. aureus WB49, S. aureus N315 and S. aureus COL were used as positive controls for the reactions.

\section{Supplementary information}

Supplementary information accompanies this paper at https://doi.org/10. 1186/s12917-020-02472-7.

Additional file 1: S1 Table. Distribuition of the non-pigmented S. aureus strains isolated from the milk of cows with clinical and subclinical mastitis, among the different states in Brazil.

Additional file 2: S2 Table. Presence of mecA and the operon crtOPQMN genes among non-pigmented S. aureus strains isolated from cows with clinical and subclinical mastitis, in different states in Brazil.

\section{Abbreviations}

WGS: Whole genome sequencing; SAC: S. aureus complex; SEs: Staphylococcal enterotoxins; TSA: Tryptone Soya Agar; SEY: Salt Egg Yolk Agar; NRPS: Nonribosomal Peptide Synthetase; MLST: Multilocus Sequence Typing

\section{Acknowledgements}

Coordenação de Aperfeiçoamento Pessoal de Nível Superior - Brasil (CAPES) and Conselho Nacional de Desenvolvimento Científico e Tecnológico (CNPq, 302383/2018-2)

\section{Authors' contributions}

ECRB and BFR contributed equally to this paper. BFR, ECRB and VLMR conceived the study. HL, MVS, RAM collected the samples. BFR, ECRB, IGC, STAD and JLG conducted the experiment. JCFP, VLMR, AFJ analyzed the results. BFR, ECRB and VLMR wrote the manuscript. All authors' reviewed the manuscript. The author(s) read and approved the final manuscript.

\section{Funding}

The Coordenação de Aperfeiçoamento Pessoal de Nível Superior - Brasil (CAPES)- Finance Code 001 supported a scholarship and Conselho Nacional de Desenvolvimento Científico e Tecnológico (CNPq, 302383/2018-2).

\section{Availability of data and materials}

All datasets generated for this study are included in the article/ Supplementary Material.

\section{Ethics approval and consent to participate}

This study was approved by the Committee on Ethics in Animal Use of UNESP (0136/2017).

\section{Consent for publication}

Not applicable.

\section{Competing interests}

The authors declare that they have no competing interests.

\section{Author details}

${ }^{1}$ Department of Chemical and Biological Sciences, Institute of Biosciences, Sao Paulo State University - UNESP, Post Office Box 510, Botucatu, Sao Paulo 18618-970, Brazil. ²Department of Hygiene Veterinary and Public Health, Sao Paulo State University, Botucatu, SP, Brazil. ${ }^{3}$ Department of Animal Science, School of Veterinary Medicine and Animal Science (USP), Pirassununga, SP,
Brazil. ${ }^{4}$ Departament of Veterinary Medicine, Federal Rural University of Pernambuco, Recife, PE, Brazil.

Received: 27 February 2020 Accepted: 13 July 2020

Published online: 20 July 2020

\section{References}

1. Ruegg PL. A 100-year review: mastitis detection, management, and prevention. J Dairy Sci. 2017;100:1038-10397. https://doi.org/10.3168/jds. 2017-13023

2. Bonsaglia ECR, Silva NCC, Rossi BF, Camargo $\mathrm{CH}$, Dantas STA, Langoni $\mathrm{H}$, Guimarães FF, Limae FS, Fitzgeraldf JR, Fernandes Júnior A, Rall VLM. Molecular epidemiology of methicillin-susceptible Staphylococcus aureus (MSSA) isolated from milk of cows with subclinical mastitis. Microb Pathog. 2018;124:130-5. https://doi.org/10.1016/j.micpath.2018.08.031.

3. Becker K, Schaumburg F, Kearns A, Larsen AR, Lindsay JA, Skov RL, Westh $H$. Implications of identifying the recently defined members of the Staphylococcus aureus complex S. argenteus and S. schweitzeri: a position paper of members of the ESCMID study Group for Staphylococci and Staphylococcal Diseases (ESGS). Clin Microbiol Infect. 2019;25(9):1064-70. https://doi.org/10.1016/j.cmi.2019.02.028.

4. Dupieux C, Blondé R, Bouchiat C, Meugnier H, Bes M, Laurent S, Vandenesch F, Laurent F, Tristan A. Community-acquired infections due to Staphylococcus argenteus lineage isolates harbouring the Panton-valentine leucocidin, France, 2014. Euro Surveill. 2015;20(23):21154 Available online: http://www.eurosurveillance.org.

5. Thaipadungpanit J, Amornchai P, Nickerson EK, Wongsuvan G, Wuthiekanun V, Limmathurotsakul D, Peacock SJ. Clinical and molecular epidemiology of Staphylococcus argenteus infections in Thailand. J Clin Microbiol. 2015;53(3): 1005-8. https://doi.org/10.1128/JCM.03049-14.

6. Tong SY, Schaumburg F, Ellington MJ, Corander J, Pichon B, Leendertz F, Bentley SD, Parkhill J, Holt DC, Peters G, Giffard PM. Novel staphylococcal species that form part of a Staphylococcus aureus-related complex: the nonpigmented Staphylococcus argenteus sp. nov. and the non-human primateassociated Staphylococcus schweitzeri sp. nov. Int I Syst Evol Microbiol. 2015; 65:15-22. https://doi.org/10.1099/ijs.0.062752-0.

7. Argudín MA, Dodemont M, Vandendriessche S, Rottiers S, Tribes C, Roisin S, De Mendonça R, Nonhoff C, Deplano A, Denis O. Low occurrence of the new species Staphylococcus argenteus in a Staphylococcus aureus collection of human isolates from Belgium. Eur J Clin Microbiol Infect Dis. 2016;35(6): 1017-22. https://doi.org/10.1007/s10096-016-2632-x.

8. Chantratita N, Wikraiphat C, Tandhavanant S, Wongsuvan G, Ariyaprasert P, Suntornsut $P$, Thaipadungpanit J, Teerawattanasook N, Jutrakul $Y$, Srisurat N, Chaimanee P, Anukunananchai J, Phiphitaporn S, Srisamang P, Chetchotisakd P, West TE, Peacock SJ. Comparison of community onset Staphylococcus argenteus and Staphylococcus aureus sepsis in Thailand: a prospective multicentre observational study. Clin Microbiol Infect. 2016;22: 458.e11-9. https://doi.org/10.1016/j.cmi.2016.01.008.

9. Zhang DF, Xu X, Song Q, Bai Y, Zhang Y, Song M, Shi C, Shi X. Identification of Staphylococcus argenteus in Eastern China based on a nonribosomal peptide synthetase (NRPS) gene. Future Microbiol. 2016;11:1113-21. https://doi.org/10.2217/fmb-2016-0017.

10. Olatimehin A, Shittu AO, Onwugamba FC, Mellmann A, Becker K, Schaumburg F. Staphylococcus aureus complex in the straw-colored fruit bat (Eidolon helvum) in Nigeria. Front Microbiol. 2018;9:162. https://doi.org/10. 3389/fmicb.2018.00162.

11. McDonald M, Dougall A, Holt D, Huygens F, Oppedisano F, Giffard PM, Inman-Bamber J, Stephens AJ, Towers R, Carapetis JR, Currie BJ. Use of a single-nucleotide polymorphism genotyping system to demonstrate the unique epidemiology of methicillin-resistant Staphylococcus aureus in remote Aboriginal communities. J Clin Microbiol. 2006;44:3720-7. https://doi.org/10.1128/JCM.00836-06

12. Holt DC, Holden MT, Tong SY, Castillo-Ramirez S, Clarke L, Quail MA, Currie BJ, Parkhill J, Bentley SD, Feil EJ, Giffard PM. A very early-branching Staphylococcus aureus lineage lacking the carotenoid pigment staphyloxanthin. Genome Biol Evol. 2011;3:881-95. https://doi.org/10.1093/ gbe/evr078.

13. Hansen TA, Bartels MD, Høgh SV, Dons LE, Pedersen M, Jensen TG, Kemp M, Skov MN, Gumpert H, Worning P, Westh $\mathrm{H}$. Whole genome sequencing of Danish Staphylococcus argenteus reveals a genetically diverse collection 
with clear separation from Staphylococcus aureus. Front Microbiol. 2017;8: 1512. https://doi.org/10.3389/fmicb.2017.01512.

14. Golding GR, Bryden L, Levett PN, McDonald RR, Wong A, Graham MR, Tyler S, Van Domselaar G, Mabon P, Kent H, Butaye P, Smith TC, Kadlec K,

Schwarz S, Weese SJ, Mulvey MR. Whole-genome sequence of livestockassociated ST398 methicillin-resistant Staphylococcus aureus isolated from humans in Canada. J Bacteriol. 2012;194:6627-8. https://doi.org/10.1128/JB. 01680-12.

15. Shi X, Zhang DF. Staphylococcus argenteus: an emerging foodborne pathogen? Curr Opin Food Sci. 2018;20:76-81. https://doi.org/10.1016/j.cofs. 2018.03.015.

16. Indrawattana N, Pumipuntu N, Suriyakhun N, Jangsangthong A, Kulpeanprasit S, Chantratita N, Sookrung N, Chaicumpa W, Buranasinsup S. Staphylococcus argenteus from rabbits in Thailand. Microbiol Open. 2019; 8(4):665. https://doi.org/10.1002/mbo3.665.

17. Bruins MJ, Van Coppenraet LEB, Wolfhagen MJ. Methicillin-resistant Staphylococcus argenteus in the Netherlands-a case report. Clin Microbiol Newsl. 2019. https://doi.org/10.1016/j.clinmicnews.2019.01.005.

18. Wakabayashi Y, Umeda K, Yonogi S, Nakamura H, Yamamoto K, Kumeda Y, Kawatsu K. Staphylococcal food poisoning caused by Staphylococcus argenteus harboring staphylococcal enterotoxin genes. Int J Food Microbiol. 2018;265:23-9. https://doi.org/10.1016/j.ijfoodmicro.2017.10.022.

19. Kim SH, Lee PC. Functional expression and extension of staphylococcal staphyloxanthin biosynthetic pathway in Escherichia coli. J Biol Chem. 2012; 287(26):21575-83. https://doi.org/10.1074/jbc.M112.343020.

20. Ohnishi T, Shinjoh M, Ohara H, Kawai T, Kamimaki I, Mizushima R, Kamada K, Itakura Y, Iguchi S, Uzawa Y, Yoshida A, Kikuchi K. Purulent lymphadenitis caused by Staphylococcus argenteus, representing the first Japanese case of Staphylococcus argenteus (multilocus sequence type 2250) infection in a 12year-old boy. J Infect Chemother. 2018;24(11):925-7. https://doi.org/10.1016/ j.jiac.2018.03.018

21. Li Q, Li Y, Tang Y, Meng C, Ingmer H, Jiao X. Prevalence and characterization of Staphylococcus aureus and Staphylococcus argenteus in chicken from retail markets in China. Food Control. 2019;96:158-64. https://doi.org/10.1016/j. foodcont.2018.08.030.

22. Moradigaravand D, Jamrozy D, Mostowy R, Anderson A, Nickerson EK, Thaipadungpanit J, Wuthiekanun V, Limmathurotsakul D, Tandhavanant S, Wikraiphat C, Wongsuvan G, Teerawattanasook N, Jutrakul Y, Srisurat N, Chaimanee P, West TE, Blane B, Parkhill J, Chantratita N, Peacock SJ. Evolution of the Staphylococcus argenteus ST2250 clone in northeastern Thailand is linked with the acquisition of livestock-associated staphylococcal genes. MBio. 2017;8(4):e00802-17. https://doi.org/10.1128/mBio.00802-17.

23. Kitagawa H, Ohge H, Hisatsune J, Masuda K, Aziz F, Hara T, Kuroo Y, Sugai M. Low incidence of Staphylococcus argenteus bacteremia in Hiroshima, Japan. J Infect Chemother. 2020;26(1):140-3. https://doi.org/10.1016/j.jiac. 2019.07.011.

24. CRL-AR, Community reference laboratory for antimicrobial resistance. Multiplex. 378 PCR for the detection of the mecA gene and the identification of Staphylococcus aureus. 379 National Food Institute. Technical University of Denmark, Copenhagen, Denmark, 2009.

\section{Publisher's Note}

Springer Nature remains neutral with regard to jurisdictional claims in published maps and institutional affiliations.

Ready to submit your research? Choose BMC and benefit from:
- fast, convenient online submission
- thorough peer review by experienced researchers in your field
- rapid publication on acceptance
- support for research data, including large and complex data types
- gold Open Access which fosters wider collaboration and increased citations
- maximum visibility for your research: over 100M website views per year
At BMC, research is always in progress.
Learn more biomedcentral.com/submissions

